ORIGINAL ARTICLE

AFRICAN JOURNAL OF CLINICAL AND EXPERIMENTAL MICROBIOLOGY_ MAY 2008 ISBN 1595-689X VOL 9 No 2

AJCEM/2008008/2812

-http://www.ajol.info/journals/ajcem

COPYRIGHT 2007

AFR. J. CLN. EXPER. MICROBIOL. 8 (2): 88 - 96

\title{
SUSCEPTIBILITY PROFILE OF YEAST-LIKE ORGANISMS ISOLATED FROM HIV/AIDS PATIENTS; USING NCCLS MACRODILTION METHOD COMPARED WITH AGAR DIFFUSION TECHNIQUE.
}

\author{
ENWURU $^{1}$ C.A; OGUNLEDUN ${ }^{2}$ A; IDIKA ${ }^{1}$ N; ENWURU $^{3}$ N.V
}

1. Nigerian Institute of Medical Research, Yaba, Lagos.

2. Department of Microbiology and Parasitology, School of Post-graduate Studies, Olabisi Onabanjo University,Ogun State, Nigeria.

3. Faculty of Pharmacy, Lagos University Teaching Hospital (LUTH) Idiaraba Lagos, Nigerian.

CORRESPONDENCE: Enwuru, C.A. Microbiology Division. Nigerian Institute of Medical Research, Yaba, Lagos. P.M.B. 2013, Yaba-Lagos.

\begin{abstract}
Yeast like opportunistic fungal infection has been reported globally amongst HIV/AIDS patients, particularly as the etiologic agent of oral thrush. Fluconazole antibiotic has been most popularly employed in treating cases of oral thrush in HIV/AIDS patients. Recent reports have recorded antifungal drug resistance amongst immunocompromised subjects. This constitutes a big problem in the management of opportunistic candidiasis. The NCCLS micro/macrodilusion sensitivity testing procedure is expensive, cumbersome and requires a level of sophistication. This study was designed to compare NCCLS M-27-A macrodilution method (expensive) with agar diffusion technique (cheap and simple), to provide a reliable rapid alternative to the new pressing need for antifungal routine sensitivity testing. Sputum specimens from 213(108 females and 105 males) HIV positive patients were plated onto SDA. The isolates were identified by morphotyping, microscopy and speciated using germ tube test, and battery of biochemical sugar fermentation; and assimilation tests. Fluconazole agar diffusion susceptibility testing was carried out on each isolate, compared with the NCCLS macrodilution sensitivity assay standard.

Of the 74 isolates tested for fluconazole sensitivity, 59(79.7\%) were sensitive (zone diameter $\geq 19 \mathrm{~mm}$, mean diameter $28 \mathrm{~mm}), 6(8.1 \%)$ were Sensitive Dose Dependent (S-DD) (zone diameter 13-18mm, mean diameter 16mm), while 9(12.2\%) were resistant (zone diameter $\leq 12 \mathrm{~mm}$ ) using agar diffusion method, matched with 58(78.4\%) sensitive MIC $\leq 8 \mu \mathrm{g} / \mathrm{ml}, 9(12.2 \%)$ S-DD MIC $16-32 \mu \mathrm{g} / \mathrm{ml}$ and $7(9.5 \%)$ resistant MIC $>64 \mu \mathrm{g} / \mathrm{ml}$ profile, using the NCCLS macrodilution assay. The differences between the test method (Agar diffusion) and the control standard method (NCCLS-M 27-A broth Macrodilution MICS) were not statistically significant using $t$-test (two tail) $(t=$ 4.302656, $\mathrm{P}=1.0)$. Among the $C$. albicans isolates, $26(86.7 \%)$ were sensitive to fluconazole. The rank of susceptibility was $C$. albicans $>$ C. tropicalis >C. krusei.

It is concluded that broncho-oro-pharyngeal Candida and other yeast-like species existed in about one third of the HIV and AIDS patients studied; in which $C$. albicans was the most prevalent, while about ten percent of all the Candida isolates were resistant to fluconazole. The reliability of germ tube production as a confirmatory test for Candida albicans in HIV infection was as high as $96.7 \%$ and is therefore, recommended for continued use. Agar diffusion compared favourably with the NCCLS macrodilution technique, hence it is recommended for routine antifungal sensitivity test on all isolates of yeast-like cells from HIV and AIDS subjects.
\end{abstract}

KEY WORDS: HIV/AIDS, oral thrush, yeast-like cells, fluconazole resistance, NCCLS vs agar diffusion technique.

\section{INTRODUCTION}

Fungal infections have been reported from the early days of HIV|AIDS epidemic (Hody-son and Rachanis, 2002). In USA death due too mycoses increased from $10^{\text {th }}$ most common infectious disease in 1980 to the $7^{\text {th }}$. in 1997 (Mc-Neil, et al 2001).

The rates of mortality for different mycoses varied markedly according to the HIV status, but were consistently higher among males, blacks and age group $\geq 65$ years of age. (Mc-Neil, et al 2001; Lamagni, et al 2001).

Mucosal candidiasis is prevalent in HIV infection and occurs in almost all the patients at sometime during the course of the HIV disease (Odds, 1994). Oropharyngeal Candidiasis (OPC) occurs in about $84 \%$ of the cases (Neil, 1996). Esophageal 
candidiasis (EC) and OPC remain the most common opportunistic infection of those infected with HIV and are considered 'AIDS Defining Illness (ADI) (Macher 1988; Jabrarisk, et al 2004).

Candida albicans (Maenza et al, 1996; Dobosz and Marczynska 2004) is the most implicated. Yeast-like cells are found globally, some occur as normal flora (C. albicans) in wet areas (cavity, genitalia, large intestine and skin) of about $20 \%$ of humans.

Other possible etiologic agents of oral thrush include C. krusei, C. tropicalis, C. parapsilosis, and C. glabrata (Hauman, et al 1993; Klein, et al 1984; Odds, 1994).

Azole, particularly fluconazole antfungal agent has been the most effective drug in the treatment of yeast-like infections (White, et al 2002).

Antifungal drug resistance is fast becoming a major problem, particularly the fluconazole amongst the immunocompromised population ( Jabra Rizk, et al 2004). According to Maenza, et al (1996), the major risk factors for fluconazole resistance were advanced immunosuppression and prolonged exposure to azoles (Andrew 2003). Again, Jones, et al (1994) and Vargas, et al (2000) confirmed switching on oral candida isolates from HIV|AIDS patients at frequency between one and two orders of magnitude higher than those of healthy control.

Lynch and Sobel (1994) reported several fold increase in MICs to azoles tested, 0.31-40.0 $\mu \mathrm{g} / \mathrm{ml}$ for fluconazole. Carrillo-Munoze, et al reported mean MIC of $5.53 \mu \mathrm{g} \mid \mathrm{ml}$ in 1999 on various yeastlike cells.

The newer classes of antifungal drugs - the echinocardins, pnemocardins and others are quite expensive and are not available in Nigeria.
The increased reports of anticandidal resistance and the expanding drug therapy options prompted the need for clinically relevant antifungal susceptibility testing (Lewis, et al 1998).

The NCCLS method is expensive, time consuming and somehow sophisticated as stated before. Other method like the E-test strip is easier but marred by high discrepancies, having only about $74.5 \%$ reproducibility.

Currently, very few studies have been carried out on the effectiveness of the new trend in the management of EC, OPC and other mucosal fungal infections including chemotherapy and drug sensitivity pattern of yeast-like isolates from immunocompromised (HIV|AIDS) population in Nigeria in particular and Africa in general.

This study was therefore designed to compare the NCCLS M 27 A macrodilusion sensitivity testing method with agar diffusion technique for easy and routine use in HIV/AIDS opportunistic infections diagnostic laboratories.

\section{MATERIALS AND METHOD ORGANISMS}

A total of 74 isolates were recovered from 213 adult patients presented with oral disorder attending ARV clinic for the first time between October, 2004 to December, 2005.

Isolates were identified by grams reaction, germ tube and battery of biochemical sugar assimilation and fermentation tests (Rohde and Hartmann et al 1980; Claderone, 2002). Isolates were stored as water suspensions until used (Pfaller, 1999). Prior to sensitivity testing, each isolate was passaged onto 2\% glucose Sabouraud Dextrose Agar (SDA) (OXOID), supplemented with chloroamphenicol $(50 \mathrm{mg} \mid \mathrm{L})$ ( Rejane, et al, 2002) to ensure purity and viability. Cell suspension adjusted to the turbidity of 
a $0.5 \mathrm{McF}$ arland standard, as described by NCCLS for Candida species were used.

\section{SUSCEPTIBILITY TESTING}

Reference antifungal powder marked 'Physicians sample' was obtained from Pfizer pharmaceuticals Lagos, Nigeria. Macrodilution susceptibility was performed according to NCCLS M-27-A Standard. The MIC end points were read visually following 72 hours incubation. The interpretative criteria for fluconazole were those published by NCCLS (2002) and are: susceptible, MIC $\leq 8 \mu \mathrm{g} \mid \mathrm{ml}$, susceptible dose dependent (SDD), MIC 16-32 $\mu \mathrm{g} \mid \mathrm{ml}$ and resistance $\geq 64 \mu \mathrm{g} \mid \mathrm{ml}$.

For agar diffusion, $150 \mathrm{~mm}$ diameter plates containing Mueller-Hinton agar (Difco Laboratories) supplemented with $2 \%$ glucose and methylene blue $(0.5 \mu \mathrm{g} \mid \mathrm{ml})$ at a depth of $4 \mathrm{~mm}$ were used. The solid agar surfaces were inoculated from the test organism suspension employed in the corresponding macrodilution procedure, before the holes were made. In the holes $0.1 \mathrm{ml}$ of the various concentrations of the fluconazoles were dispensed. The plates were incubated in the air at $35^{\circ} \mathrm{C}$, read first at 24 hours and subsequently at 72 hours.

The interpretative criteria for fluconazole agar test were those published by Pfaller, et al (1999): Sensitive, zone diameter of $\geq 19 \mathrm{~mm}$, SDD, zone diameter of $15-18 \mathrm{~mm}$, and resistant, zone diameter of $\leq 14 \mathrm{~mm}$.

\section{QUALITY CONTROL}

Quality control (QC) was performed in accordance with, the NCCLS recommendations, however, in place of C. parapsilosis ATTC 22019 (22-33mm) recommended, C. parapsilosis previously isolated in Lagos from an AIDS patient that clinically responded to a single dose of fluconazole without a repeat episode in 6 months was used; whose zones of inhibitions were consistently $20-40 \mathrm{~mm}$ for all MICs $0.625-64 \mu \mathrm{g} / \mathrm{ml}$. This was included in all the assays to check the accuracy of the drug dilution and the reproducibility of the results.

\section{RESULTS}

Seventy three $(34.7 \%)$ out of the 213 patients gave positive culture results for yeast-like species. One patient out of the culture positive ones harbored double yeast-like cells which were identified separately, bringing the total number of isolates to 74. Only $70(94.6 \%)$ of the isolates could be adequately speciated. Candida albicans 30 (40.5\%), was the most frequently isolated species, the rest were non-Candida albicans Candida (NCAC) species, Table 4.

The gender distribution, prevalence, species distribution and Frequency of the isolates have been published in a different report.

Out of the 74 isolates tested for fluconazole sensitivity, 59(79.7\%) were sensitive (zone diameter $\geq 19 \mathrm{~mm}$ [mean diameter 28mm]) 6(8.1\%) were susceptible dose dependant (S-DD) (zone diameter 13-18mm [mean diameter $16 \mathrm{~mm}$ ] , while 9(12.2\%) were resistant (Zone diameter $\leq 12 \mathrm{~mm}$ \} using agar diffusion technique table 1, compared with $58(78.4 \%\}$ sensitive $\mathrm{MIC} \leq 8 \mu \mathrm{g} \mid \mathrm{ml}, 9(12.2 \%)$ SDD MIC $16-32 \mu \mathrm{g} \mid \mathrm{ml}$ and $7(9.5 \%)$ resistant $\mathrm{MIC}>$ $64 \mu \mathrm{g} \mid \mathrm{ml}$ using NCCLS macrodilution assay method Table 2. Table 3 shows the comparative analysis of both methods. The discrepancies between the two approaches were not statistically Significant using ttest (two tail) $(\mathrm{t}=4.302656, \mathrm{p}=1.0)$.

The rank of susceptibility has been published in another eport. 
TABLE 1: $25 \mu \mathrm{g} / \mathrm{ml}$ AVERAGE ZONE OF INHIBITION PROFILE

\begin{tabular}{|c|c|c|c|c|c|c|c|}
\hline \multicolumn{4}{|c|}{$\begin{array}{l}\text { SENSITIVE } \\
\text { DIAMETER }(\geq 19 \mathrm{~mm})\end{array}$} & \multicolumn{2}{|c|}{$\begin{array}{lr}\text { SENSITIVE } & \text { DOSE } \\
\text { DEPENDENT DIAMETER } \\
(13-18 \mathrm{~mm})\end{array}$} & \multicolumn{2}{|c|}{$\begin{array}{l}\text { RESISTANCE } \\
\text { DIAMETER } \leq 12 \mathrm{~mm}\end{array}$} \\
\hline P.CODE & DIAMETER & R P.CODE & DIAMETER & P.CODE & DIAMETER & P.CODE & DIAMETER \\
\hline $\mathrm{MR} / 10 / 01$ & 39.0 & $\mathrm{MR} / 1 / 44$ & 38.0 & LU/11/21 & 14.5 & $\mathrm{MR} / 10 / 02$ & \\
\hline $\mathrm{MR} / 10 / 03$ & 29.0 & $\mathrm{ID} / 1 / 45$ & 31.5 & $\mathrm{MR} / 1 / 42$ & 17.5 & LU/10/08 & \\
\hline $\mathrm{MR} / 10 / 04$ & 38.5 & $\mathrm{ID} / 1 / 46$ & 29.0 & $\mathrm{MR} / 1 / 43$ & 13.0 & $\mathrm{LU} / 11 / 17$ & \\
\hline $\mathrm{MR} / 10 / 01$ & 38.5 & ID/1/47 & 27.5 & $\mathrm{ID} / 1 / 50$ & 18.0 & LU/11/20 & \\
\hline $\mathrm{MR} / 10 / 06$ & 24.0 & ID/1/48 & 34.0 & $\mathrm{LU} / 1 / 54$ & 17.5 & $\mathrm{MR} / 12 / 23$ & \\
\hline LU/10/07 & 3.8 & ID/1/49 & 32.5 & $\mathrm{MR} / 2 / 59$ & 13.0 & $\mathrm{MR} / 12 / 26$ & \\
\hline LU/10/09 & 18.5 & ID/1/51 & 18.5 & & & $\mathrm{MR} / 12 / 33$ & \\
\hline LU/10/10 & 41.0 & ID/1/52 & 21.0 & & & $\mathrm{MR} / 2 / 58$ & \\
\hline $\mathrm{MR} / 11 / 11$ & 30.0 & $\mathrm{ID} / 1 / 53$ & 22.0 & & & LU/2/66 & \\
\hline $\mathrm{MR} / 11 / 12$ & 29.5 & $\mathrm{LU} / 1 / 55$ & 22.5 & & & & \\
\hline $\mathrm{MR} / 11 / 13$ & 20.5 & LU/1/56 & 29.5 & & & & \\
\hline $\mathrm{MR} / 11 / 14$ & 24.0 & LU/1/57 & 38.0 & & & & \\
\hline $\mathrm{MR} / 11 / 15$ & 23.5 & $\mathrm{MR} / 2 / 60$ & 18.5 & & & & \\
\hline $\mathrm{MR} / 11 / 16$ & 32.5 & $\mathrm{MR} / 2 / 61$ & 24.0 & & & & \\
\hline $\mathrm{MR} / 11 / 18$ & 25.5 & $\mathrm{MR} / 2 / 62$ & 21.0 & & & & \\
\hline $\mathrm{MR} / 11 / 19$ & 41.0 & $\mathrm{MR} / 2 / 63$ & 26.0 & & & & \\
\hline $\mathrm{MR} / 11 / 22$ & 31.5 & $\mathrm{LU} / 2 / 64$ & 22.0 & & & & \\
\hline $\mathrm{MR} / 12 / 24$ & 32.5 & $\mathrm{LU} / 2 / 65$ & 29.5 & & & & \\
\hline $\mathrm{MR} / 12 / 25$ & 21.5 & $\mathrm{LU} / 2 / 67$ & 36.5 & & & & \\
\hline $\mathrm{MR} / 12 / 27$ & 19.0 & $\mathrm{ID} / 2 / 68$ & 24.0 & & & & \\
\hline $\mathrm{MR} / 12 / 28$ & 23.5 & $\mathrm{ID} / 2 / 69$ & 24.0 & & & & \\
\hline $\mathrm{MR} / 12 / 29$ & 19.0 & $\mathrm{ID} / 2 / 70 \mathrm{a}$ & 29.0 & & & & \\
\hline $\mathrm{MR} / 12 / 30$ & 27.5 & $\mathrm{ID} / 2 / 70 \mathrm{~b}$ & 25.0 & & & & \\
\hline $\mathrm{MR} / 12 / 31$ & 19.5 & $\mathrm{ID} / 2 / 71$ & 24.5 & & & & \\
\hline $\mathrm{MR} / 12 / 32$ & 20.0 & $\mathrm{ID} / 2 / 72$ & 27.5 & & & & \\
\hline $\mathrm{LU} / 12 / 34$ & 29.0 & $\mathrm{ID} / 2 / 73$ & 36.0 & & & & \\
\hline LU/12/35 & 29.0 & & & & & & \\
\hline LU/12/36 & 18.5 & & & & & & \\
\hline $\mathrm{LU} / 12 / 37$ & 24.0 & & & & & & \\
\hline $\mathrm{MR} / 1 / 38$ & 46.0 & & & & & & \\
\hline $\mathrm{MR} / 1 / 39$ & 31.5 & & & & & & \\
\hline $\mathrm{MR} / 1 / 40$ & 23.5 & & & & & & \\
\hline $\mathrm{MR} / 1 / 41$ & 29.0 & & & & & & \\
\hline Total & & & $\mathrm{n}=\mathbf{5 9}$ & $\mathbf{n}=$ & & $\mathrm{n}=\mathbf{9}$ & \\
\hline
\end{tabular}

Key: $\mathbf{P}$ CODE $=$ Patients'hospital code number, $M R=$ Medical Research, ID $=$ Infectious Disease hospital and $L U=$ LUTH hospital. 
TABLE 2

THE MICS OF MACRODILUTION PROCEDURE CONDUCTED

\begin{tabular}{|c|c|c|c|c|c|c|c|}
\hline \multicolumn{4}{|c|}{$\begin{array}{l}\text { SENSITIVE } \\
\text { MIC } \leq 8 \mu \mathrm{g} / \mathrm{ml}\end{array}$} & \multicolumn{2}{|c|}{$\begin{array}{l}\text { S-DD } \\
\text { MIC >8 -32 } \mu \mathrm{g} / \mathrm{ml}\end{array}$} & \multicolumn{2}{|c|}{$\begin{array}{l}\text { RESISTANT } \\
M I C \geq 64 \mu \mathrm{g} / \mathrm{ml}\end{array}$} \\
\hline P-CODE & MIC & P-CODE & MIC & P-CODE & MIC & $\begin{array}{l}\text { P-CODE } \\
\text { MIC }\end{array}$ & \\
\hline $\mathrm{MR} / 10 / 01$ & 0.625 & $\mathrm{MR} / 1 / 43$ & 8.0 & $\mathrm{MR} / 10 / 02$ & 32 & LU/10/08 & $>64$ \\
\hline $\mathrm{MR} / 10 / 03$ & 0.1 & ID/1/45 & 0.25 & $\mathrm{MR} / 10 / 06$ & $>8$ & LU/11/17 & - \\
\hline $\mathrm{MR} / 10 / 04$ & 0.25 & $\mathrm{ID} / 1 / 46$ & 1.0 & $\mathrm{MR} / 12 / 27$ & $>8$ & LU/11/20 & $>64$ \\
\hline $\mathrm{MR} / 10 / 05$ & 0.25 & ID/1/47 & 1.0 & $\mathrm{MR} / 11 / 33$ & 32 & $\mathrm{MR} / 12 / 23$ & - \\
\hline $\mathrm{MR} / 10 / 07$ & 1.0 & ID/1/48 & 0.25 & LU/12/36 & 32 & $\mathrm{MR} / 12 / 26$ & - \\
\hline LU/10/09 & 4.0 & ID/1/49 & 1.0 & $\mathrm{MR} / 11 / 44$ & 32 & $\mathrm{MR} / 2 / 58$ & - \\
\hline $\mathrm{LU} / 10 / 10$ & 1.0 & $\mathrm{ID} / 1 / 50$ & 8.0 & ID/1/51 & $>8$ & LU/12/66 & - \\
\hline $\mathrm{MR} / 11 / 11$ & 0.25 & $\mathrm{ID} / 1 / 52$ & 0.25 & $\mathrm{MR} / 2 / 59$ & 32 & & \\
\hline $\mathrm{MR} / 11 / 12$ & 0.625 & $\mathrm{ID} / 1 / 53$ & 1.0 & $\mathrm{MR} / 2 / 60$ & 32 & & \\
\hline $\mathrm{MR} / 11 / 13$ & 4.0 & $\mathrm{LU} / 1 / 54$ & 8.0 & & & & \\
\hline $\mathrm{MR} / 11 / 14$ & 1.0 & $\mathrm{LU} / 1 / 55$ & 8.0 & & & & \\
\hline $\mathrm{MR} / 11 / 15$ & 4.0 & $\mathrm{LU} / 1 / 56$ & 0.25 & & & & \\
\hline $\mathrm{MR} / 11 / 16$ & 1.0 & LU/1/57 & 0.625 & & & & \\
\hline LU/11/18 & 1.0 & $\mathrm{MR} / 2 / 61$ & 4.0 & & & & \\
\hline LU/11/19 & 0.25 & $\mathrm{MR} / 2 / 62$ & 1.0 & & & & \\
\hline LU/11/21 & 4.0 & LU/2/63 & 1.0 & & & & \\
\hline $\mathrm{LU} / 11 / 22$ & 0.25 & $\mathrm{LU} / 2 / 64$ & 4.0 & & & & \\
\hline $\mathrm{MR} / 12 / 24$ & 1.0 & $\mathrm{LU} / 2 / 65$ & 1.0 & & & & \\
\hline $\mathrm{MR} / 12 / 25$ & 0.25 & $\mathrm{ID} / 2 / 67$ & 0.25 & & & & \\
\hline $\mathrm{MR} / 12 / 28$ & 4.0 & $\mathrm{ID} / 2 / 68$ & 1.0 & & & & \\
\hline $\mathrm{MR} / 12 / 29$ & 1.0 & $\mathrm{ID} / 2 / 69$ & 4.0 & & & & \\
\hline $\mathrm{MR} / 12 / 30$ & 4.0 & $\mathrm{ID} / 2 / 70 \mathrm{a}$ & 0.25 & & & & \\
\hline $\mathrm{MR} / 12 / 31$ & 8.0 & $\mathrm{ID} / 2 / 70 \mathrm{~b}$ & 1.0 & & & & \\
\hline $\mathrm{MR} / 12 / 32$ & 4.0 & $\mathrm{ID} / 2 / 71$ & 0.25 & & & & \\
\hline LU/12/34 & 0.25 & $\mathrm{ID} / 2 / 72$ & 4.0 & & & & \\
\hline LU/12/35 & 4.0 & $\mathrm{ID} / 2 / 73$ & 0.25 & & & & \\
\hline LU/12/37 & 1.0 & & & & & & \\
\hline $\mathrm{MR} / 1 / 38$ & 0.25 & & & & & & \\
\hline $\mathrm{MR} / 1 / 39$ & 4.0 & & & & & & \\
\hline $\mathrm{MR} / 1 / 40$ & 4.0 & & & & & & \\
\hline $\mathrm{MR} / 1 / 41$ & 0.25 & & & & & & \\
\hline $\mathrm{MR} / 1 / 42$ & 8.0 & & & & & & \\
\hline
\end{tabular}

Key: P.CODE $=$ Patients' hospital code number, MR= Medical Research, ID= Infectious Disease hospital and LU= LUTH hospital.

TABLE 3: The COMPARATIVE ANALYSIS OF NCCLS MACRODILUTION AND AGAR DIFFUSION METHODS FOR FLUCONAZOLE SENSITIVITY PROFILE.

\begin{tabular}{lcccc}
\hline METHOD & $\begin{array}{c}\text { SENSITIVE } \\
\mathrm{n}(\%)\end{array}$ & $\begin{array}{c}\text { S-DD } \\
\mathrm{n}(\%)\end{array}$ & $\begin{array}{c}\text { RESISTANT } \\
\mathrm{n}(\%)\end{array}$ & $\begin{array}{c}\text { TOTAL } \\
\mathrm{n}(\%)\end{array}$ \\
\hline $\begin{array}{l}\text { NCCLS MACRO } \\
\text { DILUTION }\end{array}$ & $58(78.4)$ & $9(12.2)$ & $7(9.4)$ & $74(100)$ \\
$\begin{array}{l}\text { AGAR ZONE } \\
\text { DIAMETER }\end{array}$ & $59(79.7)$ & $6(8.1)$ & $9(12.2)$ & $74(100)$ \\
\hline
\end{tabular}

T-test (two tail) $\mathrm{t}=4.3027, \quad \mathrm{P}=1.0$

S-DD $=$ Sensitive Dose Dependent. 
TABLE 4: THE NCCLS MACRODILUTION FLUCONAZOLE SUSCEPTIBILITY PROFILES OF VARIOUS YEAST-LIKE SPECIES ISOLATED

\begin{tabular}{|c|c|c|c|c|c|c|c|}
\hline \multirow{2}{*}{$\begin{array}{l}\text { CANDIA } \\
\text { SPECIES } \\
\end{array}$} & \multirow[t]{2}{*}{ NO ISOLATED } & \multicolumn{2}{|c|}{ SENS. } & \multicolumn{2}{|c|}{ SENS. DD } & \multicolumn{2}{|c|}{ RESISTANT } \\
\hline & & NO & $(\%)$ & $\mathrm{NO}$ & $(\%)$ & NO & $(\%)$ \\
\hline C.albicans & 30 & 26 & 86.7 & 1 & 3.3 & 3 & 10 \\
\hline C. tropicalis & 13 & 11 & 84.6 & 1 & 7.7 & 1 & 7.7 \\
\hline C. krusei & 5 & 2 & 40.0 & 1 & 20.0 & 240 & \\
\hline C. glabrata & 4 & 4 & 100 & & - & & - \\
\hline C.pseudotropicalis & 3 & 1 & 33.3 & 2 & 66.7 & - & \\
\hline C.parapsilosis & 3 & 1 & 100 & 2 & 66.7 & - & \\
\hline C. famata & 3 & 3 & 100 & & - & & - \\
\hline C. kefyre & 2 & 2 & 100 & & - & & - \\
\hline C.gulliermondii & 1 & 1 & 100 & & - & & - \\
\hline R. rubra & 1 & 1 & 100 & & - & & - \\
\hline T. cutaneum & 1 & - & & & - & 1 & 100 \\
\hline C. dubliniensis & 1 & - & 1 & 100 & - & - & \\
\hline C. neoformance & 4 & 3 & 75 & & 1 & 25 & - \\
\hline Indeterminate & 3 & 3 & 100 & & - & & - \\
\hline Total NO: & 74 & 58 & 9 & & 7 & & \\
\hline
\end{tabular}

\section{DISCUSSION}

Oral thrush caused by yeast-like organisms having been reported as a common opportunistic infection amongst immunocompromised HIV and AIDS patients requires a closer marking.

That Candida albicans (40.5\%) was the most implicated has equally been reported by Ehrahim, et al (2002) and Rejane, et al (2002); 52.4\% and 57.4\% from Bahraim and Brazil respectively.

Essentially, it has been reported that all species of candida isolates from HIV and AIDS patients in America are potentially pathogenic (Jabria-Rizik, et al (2004); Colman, (1998). However, the knowledge of the particular species involved in any episode is imperative, since some species of yeasts are known to be intrinsically resistant to some antifungals eg C. krusei to fluconazole (Regane, et al 2002). Azole(Fluconazole in particular) is considered the drug of choice for the treatment of oral candidiasis associated with HIV and AIDS patients ( White, et al 2002).
Recent reports have indicated development of yeastlike cells resistance to fluconazole antifungal (Gabriel, 1991; Maenza, et al 1996; White, et al 2002; Sangeorzan, et al 1994 and Jabra-Rizk, et al 2004). Factors associated with the development of yeast-like cells resistance have been severally reported to include include: Secondary (after previous drug exposure) resistance, prolonged clinical treatment, low dosage and advanced immunosuppression (Million, et al 1994; White, et al 2002). These factors are gradually indicated in Nigerian ARV clinics.

From the result of this study, $9.5 \%$ of clinical isolates of oral thrush yeast-like organisms showed invitro resistance to Fluconazole in Nigeria. This report is in agreement with Million et al who reported 5-10\% in 1994 from Europe, but lower than 6-36\% reported by Priscila de Laet Sant' Ana, et al from Brazil, in 2002. This could be explained in concord with the peer notion that there exist intrinsic and geographical differences amongst yeast-like organisms (Jabra-Rizk et al 2000), or that resistant strains spread with each passing time. 
The sensitive C. albicans isolates had a mean MIC of $2.2 \mu \mathrm{g} / \mathrm{ml}$, (standard $\leq 8 \mu \mathrm{g} / \mathrm{ml}$ ) for macro and microdilution methods. Lynch and Sobel (1994) reported MIC of Fluconazole tested as 0.31 $40.0 \mu \mathrm{g} / \mathrm{ml}$, Pfaller; et al (1999) reported 1.25 $2.5 \mu \mathrm{g} / \mathrm{ml}$ for C. albicans. And $5.0-50.0 \mu \mathrm{g} / \mathrm{ml}$ for C. glabrata; and Carrillo-Munoze et al (1999) reported mean MIC of $5.53 \mu \mathrm{g} / \mathrm{ml}$. This relatively lower MIC reported here may be attributed to less abuse of the antifungal agent in the area studied, probably because it is not common unlike common antibacterial agents and the drug is somewhat expensive.

Having established the need for fluconazole susceptibility tests on clinical isolates of yeast cells, this report put the resource poor setting into perspective, comparing the NCCLS drug sensitivity testing standard (macrodilution) with agar diffusion method.

From the result of this study there are: 59 versus 58 Sensitive (S) group, 6 versus 9 Sensitive Dose Dependant (S-DD) and 9 versus 7 Resistant group (R). The discrepancies between the standard method (The NCCLS M27-A broth macrodilution method) and the agar diffusion method were essentially minor using $\mathrm{t}$-test (two tailed), $\mathrm{t}=4.302656, \mathrm{p}=1.0$. This report agrees with the work of Drussel, et al (1998) who reported complete agreement in percentage of the comparative study of disc diffusion method and NCCLS microdilution method.

Since there are reports of intrinsic and geographical differences between different populations of yeast cells and with the report of extensive variety in yeast species recovered from Nigeria by Jabra-Rizk et al in 2000, this report recommends intermittent if not routine susceptibility testing of all-yeast-like isolates, particularly from immunocompromised (HIV/AIDs) subjects using less cumbersome and cheaper agar diffusion technique.

\section{REFERENCES}

1. Hodyson, T. A.; Rachanis C. C. (2002): Oral fungal and bacterial infection in HIV-infected individuals: an overview in Africa. Pub. Med. Journal National Library of Medicine UK. 8 Suppl. 2: 80 - 7.

2. McNeil, M.M.; Nash, S.L.; Hajjeh, R.A.; Phelan, M. A.; Conn, L.A.; Plikaytis, B.D.; Warnnock, D.W. (2001). Trends in Mortality due to invasive mycotic diseases in the United States 1980 - 1997. Clinical Infect. Dis. 1; 33(5): 641 -7

3. Lamagni, T.B.; Evans, B.G.; Shigematsu, M., Johnson, F.M.(2001): Emerging trends in the epidemiology of inversive mycoses in England and Wales. Epidemiol-Infec 126(3): 397-414.

4. Odds, F.C. (1994). Candida species and Virulence, ASM News 60: 313 - 318.

5. Neil M. Ampel, M. D. (1996): Emerging Disease Issues and Fungal pathogens Associated with HIV infection. Emerging Infectious Diseases. 2 (2): 1 -11 .

http:www.cdc.gov/ncidod/eid/vol2no2/ampel.htm

6. Macher, A. M. (1988). The pathology of AIDS. Public. Health Rep. 103: 246 - 250.

7. Jabra-Rizk, M. A.; Falker, W. A.; Meiller, T. F. (2004) Fungal Biofilms and Drug Resistance. CDC J. Emerging Infections Diseases www.cdc.gov/eid.vol.10 No.1

8. Maenza, J. R. (1996): Risk fators for Fluconazole Resistant Candidiasis in HIV-infected patients. J. Infec. Dis. 173: 219. http:/www.thebody.com/jh/moore/mar96/snapshol. $h t m l$

9. Dobosz, S. Marczynska, M. (2004).The most common pathologic syndromes in HIV - infected children. HIV/AIDS Rev. 3(1): 51-53

10. Hauman, C. H.; Thompson, I.O.; Theunissen, F.; Wolfaart, P. (1993): Oral carriage of candida in health and HIV seropositive persons. Oral. Sarg. Med. Oral Pathol. 76: 570 - 572.

11. Klein, R. S.; Harris, C. A.; Small, C. B.; Moll, B.; Lesser, M; Friedland, G. H. (1984). Oral candidiasis in high-risk patients as the initial manifestation of the acquired immunologic 
deficiency syndrome. N. Engl. J. Med. 311: 354 358.

12. White, T. C.; Hollemann, S.; Dy, F.; Mirels, L. F.; Stevens, D.A. (2002). Resistance mechanisms in clinical isolates of Candida albicans. Antimicrobial Agents Chemother. 46: 1704-13.

13. Andrew, B. (2003): More common opportunistic Infections; their symptoms, diagnosis, prophylaxis and treatment Positive (+ve) Magazine issue 42 (June, 2003) pp 1 of 10 htt://wwwhoshat.co.uk/03/06/030606htm

14. Jones, S.; White, G.; Hunter, P.R. (1994). Increased Phenotypic switching in strains of Candida albicans associated with invasive infections. J. Chin Microbiol 32 2869-2870.

15. Vargas, K.; Messer, a. Pfaller, M.; Lockhart, S.R.; Stapleton, J.T.; Hellstein, J.; soll, D.R. (2000). Elevated Phenotypic switching and drug resistance of Candida albicans from immunodeficiency virus -positive individuals prior to first thrush episode.

J. Clin. Microbiol. 38: 3595-3607.

16. Lynch, M.E.; Sobel, J. (1994). Comparative invitro activity of antimycotic agents against pathogenic vaginal yeast isolates. Journal of Medical Vetnary Mycology. 32 (4) 267-74.

17. Carrillo-Mounoz, A.J.; Quindos, G; Tur-C; Ruesga, M.T; Miranda Y,Del-valle O.Cossum, A.Wallace-T. L. (1999). Invitro antifungal activity of liposomal Amphotericin B, Amphotericin B Lipid complex, Amphotericin B desoxycholate Fluconzole and Itraconazole. Journal of Antimicrob-Chemotherapy. 44 (3) 397 - 401.

18. Leweis, RE; Kepser, ME; Pfllen, M.A. (1998). Update on clinical antifungal susceptibility testing for Candida species. Pharmacotherapy. 18 (3): $509-15$.

19. Rohde, B; Hartmann, G.; Haude, D.; Kessieler, H. G.; and Langen, M.L. (1980). Introducing Mycology by examples. Presented by schering Aktiengesellschaft. Hamburg. 35 - 98.

20. Calderone, R.A. (2002): Candida and Candidiasis ASM press. American Society for Microbiology 1752 N. Street. N.W. Washinton D.C. 20036 PP3 451.
21. Pfaller, M. A.; Messer, S. A.; Hollis, R. J; Jones, J. N.; Doern, G. V.; Bran dt, M. E.; hajjeh, R. A. (1999). Trends in species distribution and Susceptibility to fluconazole among blood Stream Isolates of Candida species in the United States. Diagn. Microbiol. Infect. Dis. 33: 217 - 222.

22. Rejane, P. N.; Maria, A. C.; Guilherme, M. C.; Ohane, M.C.M. (2002). Yeasts isolated from clinical samples of AIDS patients. Braz. Journal of Microbiology. 33 ( 4) : 1517-8382.

23. NCCLS (2002). M27-A2 Vol. 22 No.15: Reference method for Broth Dilution Antifungal Susceptibility Testing of Yeasts - Approved Standard $2^{\text {nd }}$ Edition.

24. Ehrahim, R.A.; Farid, E.M.; Yousif, A.; Jamsheer, A. E. (2002) Microbiological infections in HIV positive bahraini patients with low CD4+ Tlymphocyte count. Bahrain Journal of commun. Dis. 34(3): 160 - 70.

25. Coleman, D.C.; Rinaldi, M.G.; Haynes, K.A.; Rex, J.H.; Summerbell, R.C.; Anaissie, E.J.; Li, A.; Sullivan, D.J.(1998).Importance of Candida species other than Candida albicans as opportunity pathogens. Med. Mycol. 36 (suppl.1): 156-165

26. Gabriel Torres, M.D. (1991). 'An ounce of prevention update on Prophylaxis for Fungal Infection' Gay Men's health Crisis Treatment Issues. 5: 7.

http://www.aegis.com/gmhc/1991/GM050702.html

27. Sangeorzan, J. A.; Bradley, S. F.; He, X,; Zarians, L. T. (1994). Epidemiology of oral candidiasis in HIV-infected patients; Colonization, infection, treatment and emergence of fluconazole resistance. American Journal of Med. 97: 339 - 46.

28. Million, L. (1994). Fluconazole - resistant recurrent oral candidiasis in human immunoideficiency Virus positive patients: persistence of Candida albicans strains with the same genotype. J. Clinical Microbiology. 32 (4): $1115-1118$

29. Priscilla de Laet Sant'Ana, ; Milan, E. P. ; Martinez, R. ; Telles, F.Q. ; Ferrira, M. S. ; Alcantara, A.P. ; Carvalho, M.T.; Colombo, A. L. (2002). Multcenter Brazilian Study of Oral Candida species Isolated from Aids Patients. Mem. 
Inst. Oswaldo Cruz, Rio de Janeiro. 97(2):253257.

30. Jabra-risk, M. A.; Falkler, W.A; Enwonwu, C.O.; Onwujekwe, D.I.; Merz, G.; Meiller, T. F. (2000) Prevaslence of yeast among children in Nigeria and the United States. Oral Microbial Immunol. 16: $383-385$.
31. Durssel, C.; Haoui-Hassani, A.M.; Bille, J. (1998): Biomic video reading Fluconazole agar disk diffusion susceptibility testing of Candida Spp. Clinical isolates compared to NCCLS Microbroth dilution. Intersci. Conf. Antimicrob. Agents Chemother. 38: 485 (Abstract no. J-120). AIDS / 20711147. 